\title{
Comparing Indonesia and Malaysia Public Budgeting Process
}

\author{
Indrawati Yuhertiana*, Dwi Suhartini, Oryza Tannar
}

Accounting, Economics and Business Faculty, Universitas Pembangunan Nasional "Veteran” Jawa Timur, Indonesia

*Corresponding author:

E-mail:

yuhertiana@upnjatim.ac.id

\begin{abstract}
This research is exploratory research that aims to understand the government budgeting process. Reforms to manage government for a better, more professional, and modern way has been initiated by the concept of new public management. Therefore, it is important to know the process of this change taking place. One of the outcome changes which is the concern of this research is the transparency of financial information that is conveyed to the public. Therefore, observations were made on the official government website. This study focuses on observing the process of change that occurred in the two countries of Indonesia and Malaysia. The research was conducted by combining literature studies and website studies, with the content analysis method. The study found that the budgeting process is different due to different budgeting systems. However, it has similarities in the stages used, starting from planning, budgeting, implementation, and monitoring evaluation.
\end{abstract}

Keywords: Budgeting process, new public management, website, content analysis, literature review

\section{Introduction}

Public sector budgeting is a plan for introducing programs that deal with objectives and goals within a period, including an estimate of resources required, usually compared with past periods and showing future requirements. Also, the budget can be interpreted as an estimate of expected cash receipts and expenditures for the coming period. On the other hand, public budgeting is identical to budget politics, so that problems of interest often arise, and of course, these are related to behavior. Therefore, there will always be issues that surface and are voiced out by certain groups of people in terms of the allocation and distribution of the public's money. There is also a conflict of interest between the ruling government and the opposition, which creates political uneasiness and disintegration amongst political parties and the government. This study aims to provide an overview of the budgeting process in two Asia countries, namely Indonesia and Malaysia.

Previous research on the budgeting process has been widely carried out. The XX study also compared two countries. However, research A which compares the budgeting process in Malaysia and Australia examines the budgeting process in the realm of the private sector. His quantitative research succeeded in explaining the participatory budget process, how the formulation succeeded in explaining the success of the budgeting process in the company. This research is different because it elaborates on the actors involved in government budgeting. Of course, different environments cause the determinants of success in the government budgeting process to be different. On the other hand, Bastian stated that the budgeting cycle in government is complex and complicated because of the intersection between the budgeting process.

The history of new public management, which has inspired many studies, encourages this research to be carried out. As is well known, new public management as a modern government management movement has been introduced since 1991. Many countries have implemented this concept and it has been proven to have helped improve services to the community, although on the 
other hand many think that new public management is not successful. Osbornr, 2007, responded that the idea of change brought about by the flow of new public management is a very big job.

New public management focuses on performance-oriented public sector management. The use of the New Public Management paradigm has had several consequences for the government, including demands for efficiency, cost-cutting, and tender competence. New Public Management provides a quite drastic change in public sector management from a traditional management system that seems rigid, bureaucratic, and hierarchical to a public sector management model that is flexible and accommodates the market. These changes are not just small and simple. These changes have changed the role of government, especially in terms of the relationship between government and society (Nouri \& Parker, 1998).

Therefore, this study elaborates the budgeting process in two Asian countries, which are geographically close together, including an allied country, Malay, which is culturally close. It is hoped that this research will bring insight into how a country processes its managerial management which is reflected in its budgeting process. For this reason, research is carried out through a literature review as well as observing the official websites of the governments of the two countries.

\section{Material and Methods}

This research is exploratory research that aims to elaborate the process of change in public budgeting due to new public management. Literature review and website approaches are used to extract data. The data obtained is then processed using content analysis. The following is the database used and the main literature sources used.

Comparative analysis is used to process data obtained from secondary data on the official website of the government budget maker. There are 3 websites in each respective country observed that the website of the government, heads of state, heads of government, legislative, ministry of finance, and the state auditor. Results of the study showed that the process of budgeting rule is different due to the system of government which is not the same.

\section{Results and Discussion Summary of demography}

As research that explores phenomena in the public sector, it is necessary to understand the characteristics and demographics of each country. The following table explains that geographically, Indonesia is a vast country with a larger population than Malaysia.

Table 1. The demographic differences in Indonesia and Malaysia

\begin{tabular}{|c|c|c|}
\hline Information & Indonesia & Malaysia \\
\hline $\begin{array}{l}\text { Government Sys- } \\
\text { tem }\end{array}$ & Republic & $\begin{array}{l}\text { Royal Federation of Constitutional Monar- } \\
\text { chies }\end{array}$ \\
\hline President & H. Ir. Joko Widodo & Yang Pertuan Agung Muhammad V \\
\hline Prime Minister & $\begin{array}{l}\text { President as Head } \\
\text { of State and Head of Gov- } \\
\text { ernment }\end{array}$ & $\begin{array}{l}\text { The Prime Minister as the Implement- } \\
\text { ing Government of the State }\end{array}$ \\
\hline Total Population & $269,536,482$ inhabitants & $32,042,458$ inhabitants \\
\hline Area & $1,990,250 \mathrm{~km}^{2}$ & $329,750 \mathrm{~km}^{2}$ \\
\hline $\begin{array}{l}\text { Number of Prov- } \\
\text { inces }\end{array}$ & 34 provinces & 13 provinces \\
\hline $\begin{array}{l}\text { Number of Regen- } \\
\text { cies }\end{array}$ & 416 districts & 134 districts \\
\hline Number of Cities & 98 cities & 134 districts \\
\hline
\end{tabular}




\section{The Government}

State of Malaysia

$\checkmark$ Government system

The system of government adopted by Malaysia is parliamentary. The parliamentary system used by Malaysia is modeled on the Westminster parliamentary system, which was a legacy of the British Colonial Rulers. In practice, however, power was concentrated in the executive rather than in the legislature, and the judiciary was weakened by continued pressure from the government during Mahathir's era, the judicial power was shared between the federal and state governments. In the Malaysian government system, the head of government is the prime minister.

Malaysia's political system can be said to be a democracy, this can be seen from the distribution of power and the implementation of elections, although on closer inspection it is not very democratic because it is not fair. In Malaysia, like most other countries the power of the State consists of the executive, legislative and judiciary bodies.

- Exclutive power

a. Prime minister as head of government

b. King / Sultan Yang di-Pertuan Agung as head of state

c. The prime minister is a member of the lower council (People's Council), which is approved by Yang di-Pertuan Agong and has the support of a parliamentary majority

d. The cabinet is elected from the members of the People's Council and the State Council who are members of parliament

- Legislative power

a. using a bicameral system consisting of the senate (State Council) and the House of Representatives (People's Council).

b. Parliaments at the fellowship level, each state has a unicameral legislative council (Dewan Invitation Negeri) whose members are elected from single-member constituencies.

c. The Senate is appointed by the supreme leader while the remaining 26 are appointed by state legislative bodies.

d. HoR members are elected by popular vote for a term of 5 years.

- Judicial power

a. Federal court judges are appointed by the supreme leader on the advice of the prime minister.

b. The judge is the most important person who has the power to declare parliamentary action unconstitutional and ultra vires following the obligations of the Constitution and their understanding of the law

Form of government

The form of government in Malaysia is a constitutional monarchy, which is in the form of a royal state that is governed by the constitution, where the head of state is a king called Yang diPertuan Agong (Raja Malaysia). Yang di-Pertuan Agong was chosen from and by the nine Sultans of Malaya Countries, to serve five years in rotation; the other four leaders of the country, who had the title of governors, did not participate in the elections.

\section{Form of state}

Malaysia is a state that is in the form of a federation, where Malaysia consists of thirteen states and three partnership territories, namely the Kuala Lumpur, Labuan Island, and Putrajaya alliance as a federal administrative area. Each state has an assembly, and the state government is headed 
by a chief minister (chief minister). where the chief minister in each state is appointed by the state assembly.

In a federal state like Malaysia, there is federal power and state power. Matters relating to the state as a whole are left to the federal power. In certain cases, for example, entering into international agreements or printing money, the federal government is free from the state and in that field the federal government However, for matters relating to the state only and not including national interests, it is left to the powers of the states. So, in such matters, the state government is free from the federal government, for example, about culture, health education.

\section{State of Indonesia}

$\checkmark$ Government system

The Indonesian government system adheres to a presidential system and does not purely adhere to the Trias Politica, because in addition to legislative, executive, and judicial powers, there are still examinations and inspections (BPK). To determine people's representatives in the legislature as well as the head of government and representatives in the form of an independent election institution general, both at the central or state level, and district or city level.

- Exclutive power

a. Implemented by a president

b. Apart from the head of state, it is also the head of government

c. The president and vice president are elected by the people through elections, not from the winning party

d. The President has the right to elect his cabinet

e. approve the bill

- Legislative power

a. Implemented by the DPR / DPD, namely as follows;

$>$ Oversee the nets of government.

$>$ Filed a bill

b. The DPR can approve and reject international agreements

c. MPR members appoint and dismiss the president and vice president according to the supervision of the people and various institutions

- Judicial power

a. Implemented by the MA (Supreme Court)

b. The Chief Justice is elected by the Supreme Court justices and the Supreme Court justices proposed by the KY (Judicial Commission)

c. The Supreme Court has the final cassation authority in a case.

d. The Supreme Court has the authority to cancel or declare a judge's decision that is not following the Constitution.

e. The Constitutional Court has the right to review laws

Forms of government

Indonesia adheres to a form of government of the Constitutional Republic, which is a form of government led by a president. The power of the president is limited by the Constitution or the constitution. The President of the Republic of Indonesia holds the power as both head of state and head of government. This is based on Article 4 Paragraph 1 which reads, "The President of the Republic of Indonesia holds governmental power according to the Constitution". Thus, the government system in Indonesia adopts a presidential government system. The presidential system is a system of government in the republic where the executive power is elected through elections and separated from the legislative power. 


\section{$\checkmark$ Forms of state}

Based on Article 1 Paragraph 1 of the 1945 Constitution, the State of Indonesia is a unitary (decentralized) state in the form of a republic. Based on this, it can be concluded that the form of the Indonesian state is unitary, while the form of government is the republic. A unitary state is a sovereign state that is organized as a single unit in which the central government is the highest and the subnational units only exercise the powers that are chosen by the central government to delegate.

\section{$\checkmark$ Budgeting process}

- Budgeting process in Indonesia

The Unitary State of the Republic of Indonesia is a country whose management adheres to a decentralized system. It is divided into central government and local government. The central government consists of ministries and institutions. Local government consists of provisional government and district or city government. The central government budget is known as the Government Budget and State Expenditure (APBN). At the local government level, the budget is known as the Regional Revenue and Expenditure Budget (APBD). In essence, the budgeting process at the central and local governments has the same cycle. Starting with planning, stipulating, implementing, reporting, monitoring, and accountability (Figure 1).

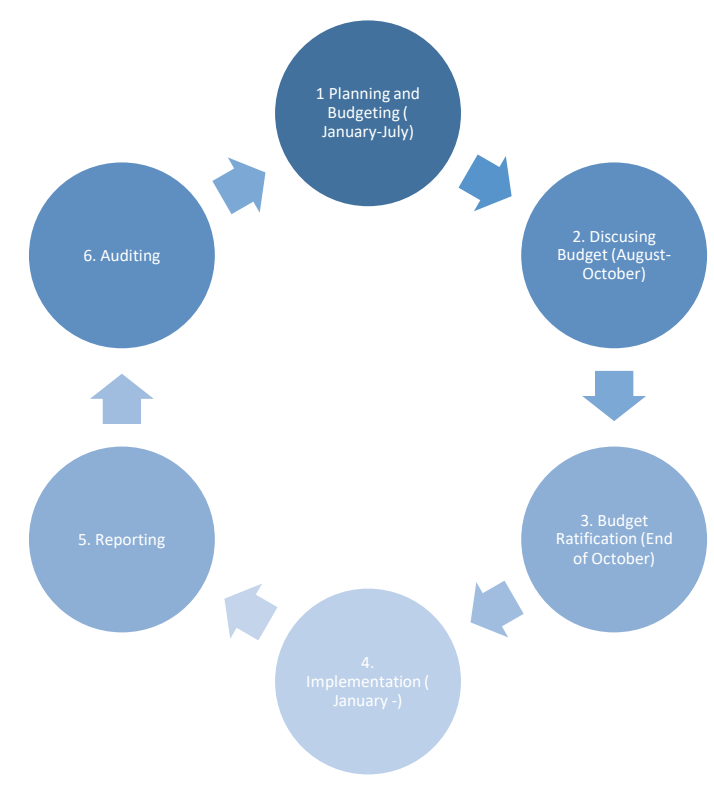

Figure 1. The planning, stipulating, implementing, reporting, monitoring, and accountability

Indonesia is a large and sprawling country that has been independent for 75 years. As an independent country, Indonesia has a constitution that regulates how this government is run. Therefore, the budgeting process has been regulated in the Indonesian constitution. In essence the budgeting process in Indonesia. the benefits of public sector budgets, namely: a) All activities can lead to the achievement of common goals b) Can be used as a tool to assess mutual advantages and disadvantages c) Can motivate employees d) Create certain responsibilities on employees e) Avoid waste and unnecessary payments f ) Resources such as labor, equipment, and funds can be used as efficiently as possible g) Educational tools for managers Public sector budgets have several main functions, namely: (1) as a planning tool, (2) a means of control, (3) fiscal policy tools, (4) political tools, (5) coordination, and communication tools, (6) performance appraisal tools, (7) motivation tools. As a system, public sector budget planning has undergone many developments. 
The public sector budget planning system develops and changes following the dynamics of the development of public sector management and the development of demands that arise in society (Anthony \& Govindarajan, 2007).

- Budgeting process in Malaysia

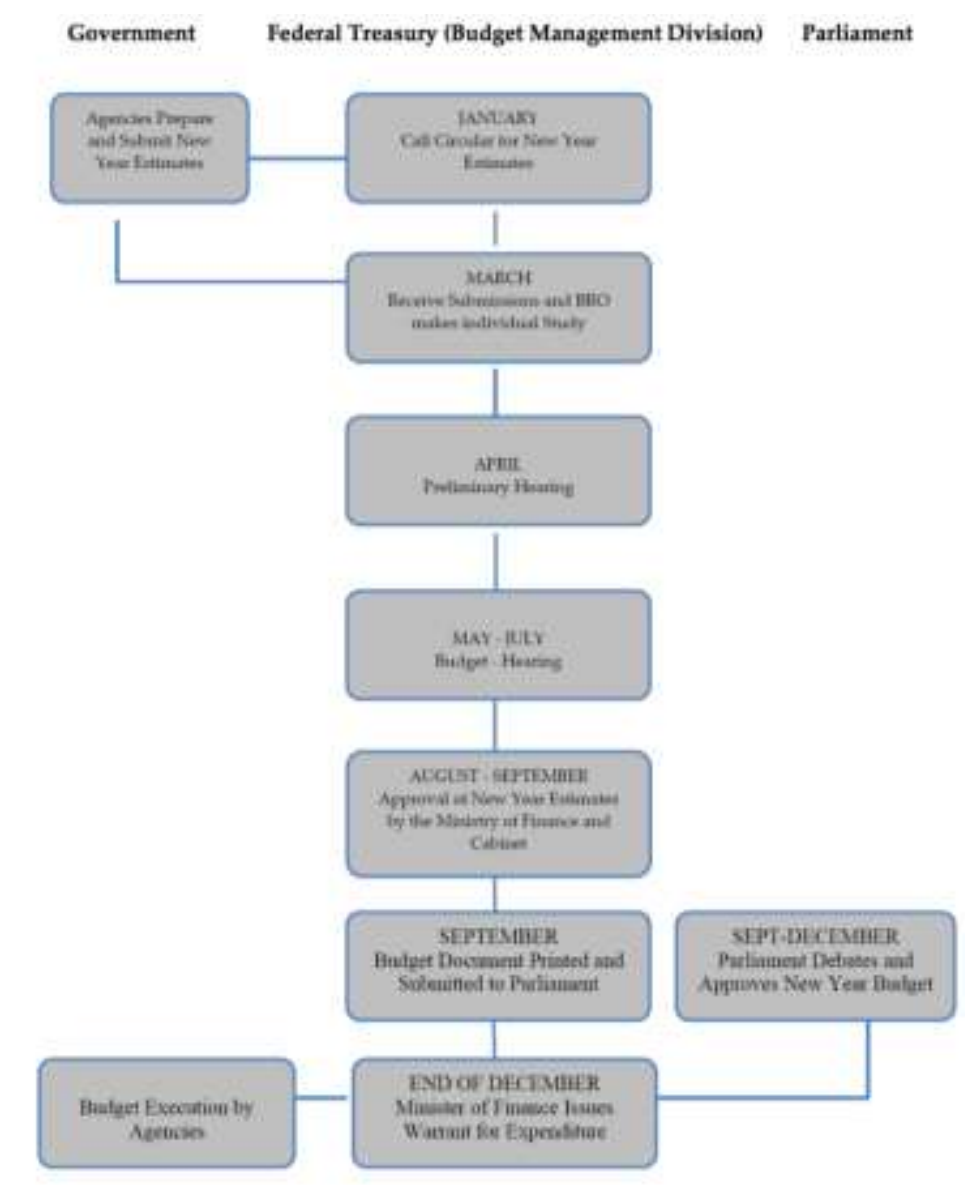

Figure 2. Malaysia: Flow of Budget formulation process Source: Sin \& Aslam, 2013

The government budgeting process starts from the planning, ratification, implementation, reporting, inspection, and accountability stages. The budgeting process in each country is different because it is determined by the system of government of each country

\section{Malaysia}

In Malaysia, the policy is governed by the Federal Constitution. Specific requirements regarding financial control and management, as well as financial and accounting procedures, are set out under the Financial Procedures Act 1957. Accounting and reporting procedures and practices are governed by a set of rules. Among the accounting procedure assistant regulations for government are the Federal Constitution (Revised 1972), the Financial Procedures Act, 1957 (Revised 1972), and the Auditing Act 1957 (Revised 1972). This law provides limited and general provisions regarding the financial, budgeting, accounting, and auditing aspects of government. Subsequently, the Ministry of Finance had instructions and circulars regarding new and requirements regarding accounting procedures. The Malaysian legal system has not changed because it has higher compensation. Although rules and laws are governing the federal budget, the Executive, Cabinet or 
government has strong control over financial resources. Distribution of indirect financial resources. We believe this is skewing towards political goals of necessity or neglecting society from racial or political thought.

January: Circular letters for the ministry and agencies are issued

March: The Ministry of Finance (MoF) or Treasury will receive fiscal advice in March.

April: preliminary hearing

May-July: Budget hearing

August - September: Budget Reading

Upon Cabinet approval, the budget will be printed and documents by September. This budget document will then pass through the Lower House of Parliament from September to December for debate and approval. Members of Parliament are usually given sufficient time to debate expenditure proposals. In certain circumstances, they are allowed to change government priorities and spending plans as needed with full access to ministers and bureaucrats who will provide further details on the budget. After all budget issues are accepted and approved by the People's Council and the Senate (State Council), the Minister of Finance will then issue a decree.
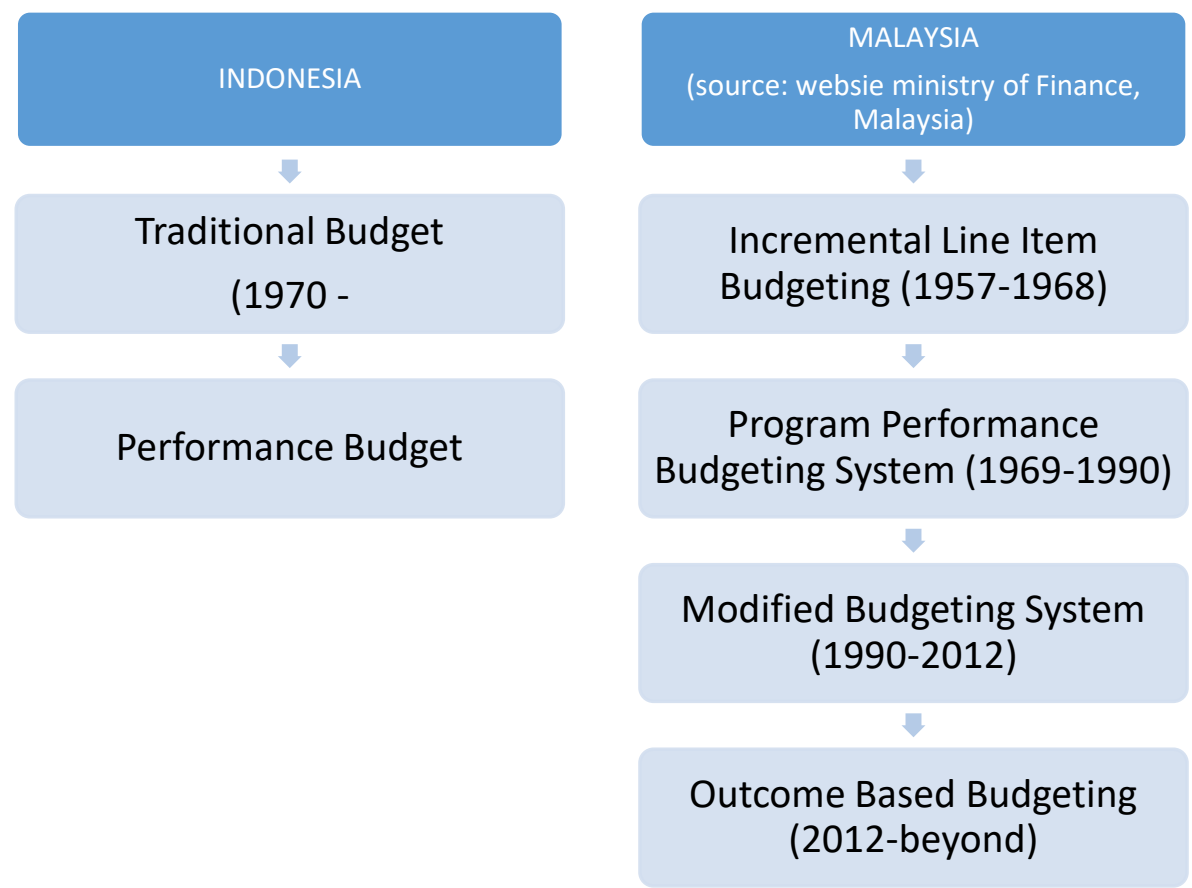

Figure 3. The different budget of Indonesian and Malaysia

The budget system in Indonesia initially followed the traditional budgeting system which ended in stages until the 1970/1971 budget year for the development budget, while the traditionally prepared routine budget ended in 1973/1974. The traditional budget system places more emphasis on the aspects of budget execution and supervision. In implementation what is important is the number of rights of each department/institution following the object and has been justified if it is following the prevailing rules and procedures. Meanwhile, in the supervision, what is prioritized is the validity of transaction evidence and the fairness of the financial statements. Issues of concern in the traditional system include 1. Budget management, namely the preparation of revenue and expenditure estimates; 2 . Ratification by the competent authority; 3 . Spending; 4 . Recording of revenue and expenditure realization by the treasurer; and, 5 . Cash accountability in the form of accountability for expenditure realization (Scott, 2012). 
a. Then to improve the budgeting process changes have been made through Law No.17 of 2003 concerning State Finance. The inclusion of a development plan in a five-year national planning document stipulated by law is deemed unrealistic and increasingly incompatible with the dynamics of the need for governance in the era of globalization. The dynamic development of government administration requires a financial planning system consisting of an annual budgeting system implemented following the MediumTerm Expenditure Framework as implemented in most developed countries. Even though the budget can be structured well, if the determination process is late it will potentially cause problems in its implementation. Reform is also carried out by implementing performance-based budgeting. Steps to fully implement performance-based budgeting in the public sector, it is also necessary to change the classification of the budget to suit the classification used internationally. Therefore, state expenditures are broken down by organization, function, and type of expenditure.

b. In the case of Malaysia, as observed, the budget policy is associated with the long or medium-term economic development plans that are drafted, current thinking or thought of economic policies, and additional measures that would be introduced probably related to major economic events such as the impact of financial or global economic crises. Also, the budget includes economic policies according to the ruling party's manifesto and promises made during the election. Even though the budget is the ruling government's privilege but the government's financial plan, i.e the allocation and the manner of spending, taxation, and borrowing are subject to law, acts, rules and procedures. The ruling government cannot simply utilize economic resources for its political means or interests. This paper argues that there is a solid link between the ruling political party with the preparation of the budget policy. To examine the matter this paper uses the survey method. This paper has found that in the case of Malaysia the Member of Parliaments does influence the outlining of the annual budget. Gulam Hassan, Mohamed Aslam \& Tan, Yee Shin, 2012. "Political Economy of The Budgetary Process in Malaysia," MPRA Paper 37873, University Library of Munich, Germany (Chin-Chun \& Ni, 2013).

In summary describes among other systems perspective budgeting Malaysia move started on the system traditionally the 1957-1968 era, system of budgeting based on the performance of the program (Program and Performance Budgeting System / PPBS) (1969-1990), the system of budgeting modification (Modified Budgeting System / MBS) (1990-2010) and the system of budgetingbased Outcome (Outcome-based budgeting / OBB) (2011-2015).

MBS started was introduced in the year 1990is as a system of management that is designed to build linkages logically on the relationship between input, output, and impact. The application of MBS is to improve the allocation of resources through management programs of government that are more efficient and increase accountability.

The main objectives of SBM for improving government financial management are:

$>$ To improve and modernize the process of allocation of sources of power based on performance,

$>$ To delegate authority management are more substantial to the level that is low to be implemented,

$>$ To introduce management based on results and cost-effectiveness.

In its application, MBS still has some issues among others:

$>$ Too much emphasis on technical aspects and ignores human variables.

$>$ Lack of attention in developing understanding, acceptance, and ability to use data.

$>$ Not inadequate support from administrator level above. 
Lack of trained staff.

Not inadequate support from the Ministry of Finance's own.

$>$ Promotional staff trained on tasks that do not relate.

To overcome the problem of MBS, the Government of Malaysia to apply the system of budgeting new, namely Budgeting Based Results (OBB) which is expected to be adopted within three years to the front in the sector of the public. The aim is to ensure the achievement of the concept of value for money, which is efficient, effective, and economical, in the management of budget expenditure. OBB is a system that integrates the use of purpose, mission, and purpose to explain the reason for the money that is spent to achieve the results specified and allow maker policies to determine the activities that saving costs to achieve the priority nationally. The purpose application of OBB is used to overcome the weaknesses and problems were encountered when applying MBS. Countries that have successfully implemented OBB are New Zealand and Canada.

\section{Conclusion}

The study found that the budgeting process is different due to different budgeting systems. However, it has similarities in the stages used, starting from planning, budgeting, implementation, and monitoring evaluation.

\section{Acknowledgment}

The authors gratefully acknowledge financial support from University Pembangunan Nasional Veteran Jawa Timur for "Kerjasama Luar Negeri" Grant 2020. The authors also thank Dr. Ketut Sari as a discussant on International Research Month Seminar for her comments.

\section{References}

Anthony, R., \& Govindarajan, V. (2007). Management control system. 12 ed. McGraw-Hill: NY, US.

Chin-Chun, S., \& Ni, F-Y. (2013). Budgetary participation and slack on the theory of planned behavior. The International Journal of Organizational Innovation, 5(4). 1-9.

Nouri, H., \& Parker, R. J. (1998). The relationship between budget participation and job performance: The roles of budget adequacy and organizational commitment. Accounting, Organizations and Society, 23(5-6), 467-483.

Scott, W. R. (2012). Financial accounting theory. New Jersey: Prentice Hall Inc.

Shin, T. Y., \& Aslam, M. (2013). Malaysia: Members of parliament and the budget plan. JATI-Journal of Southeast Asian Studies, 18, 4359. 